DOI https://doi.org/10.30525/978-9934-26-038-4-11

\title{
ВЗАЕМОЗВ'ЯЗОК СТАНУ ІМУННОЇ СИСТЕМИ З ПОКАЗНИКАМИ СИСТЕМИ ГОРМОНАЛЬНОЇ РЕГУЛЯЦЇ̈ ПРИ ВАГІНАЛЬНОМУ НОРМО- ТА ДИСБІОЗІ
}

\author{
Грузевський О. А.
}

кандидат медичних наук, доцент, завідувач кафедри мікробіології, вірусології та імунології Одеський національний медичний університет

Ніколаєва О. В. кандидат біологічних наук, асистент кафедри мікробіології, вірусології та імунології Одеський національний медичний університет

\section{Кобильник С. М.}

асистент кафедри мікробіології, вірусології та імунології Одеський начіональний медичний університет

Кагляк М. Д. асистент кафедри мікробіології, вірусології та імунології Одеський національний медичний університет

\section{Табуліна А. М.}

асистент кафедри мікробіології, вірусології та імунології Одеський національний медичний університет м. Одеса, Україна

Мета дослідження: встановити взаємозв'язок низки показників імунної системи 3 показниками системи гормональної регуляції при нормо- та дисбіозі

Бактеріальний вагіноз (БВ) - це загальний інфекційний незапальний синдром, пов'язаний з дисбіозом вагінального біотопу, що супроводжується надмірно високою концентрацією облігатно- і факультативно-анаеробних умовно патогенних мікроорганізмів і різким зниженням вмісту або відсутністю Lactobacillus spp. у виділеннях піхви. Частота БВ за останнє десятиліття зросла в два рази і становить, за даними різних авторів, від $26 \%$ до 40-45\% [1, с. 472]. БВ є найпоширенішою причиною появи незвичайних виділень 3 піхви жінок дітородного віку і виявляється у $35 \%$ жінок, що звертаються до шкірно-венерологічних 
диспансерів, у 15-20 \% вагітних, у 5-15 \% жінок, що спостерігаються у гінекологів [2, с. 428-430].

За останніми даними БВ - це порушення екосистеми піхви, при якому природні захисні механізми, такі як мікробіоценоз піхви, фізіологічна десквамація епітелію, синтез антимікробних речовин, забезпечення локального імунного захисту (як клітинної, так і гуморальної ланки) перестають працювати і дають можливість розмножуватися різним видам мікроорганізмів [3, с. 73-77; 4, с. 59-64].

Для БВ характерна відсутність системної і місцевої запальної реакції, хоча у піхві виявляють підвищені рівні прозапальних цитокінів IL1 $\alpha$ і IL1 $\beta$. 10-20-кратне збільшення рівня IL1 $\beta$ корелює зі збільшенням кількості G. vaginalis. Вивчення рівня хемотаксину IL-8, який відповідає за залучення в осередок запалення поліморфноядерних лейкоцитів, показало, що при БВ відбувається його швидка деградація за рахунок протеолітичної активності облігатних анаеробів, які швидко розмножуються [5, с. 70-73].

В рамках відбору пацієнток для даного дослідження обстежені жінки у віці від 16 до 64 років, які звернулися до гінеколога для профілактичного огляду або з приводу скарг на дискомфорт в області геніталій різного ступеня прояву. Вміст інтерлейкінів $1 \beta$ (IL1 $\beta$ ), 4 (IL4) в крові і вагінальній рідині проводили методом ІФА 3 використанням тестсистеми виробництва ТОВ «Вектор-Бест» (РФ): «Интерлейкин-1-бетаІФА-БЕСТ», «Интерлейкин-4-ІФА -БЕСТ». Концентрацію лютеотропного гормону (ЛГ), фолікулостімулюючого гормону (ФСГ) в сироватці крові визначали методом ІФА з використанням комплектів реактивів виробництва НПЛ «Гранум» (Україна): «ЛГ - ІФА», «ФСГ - ІФА». Кількісне визначення кортизолу (КР), прогестерону (ПГ), естрадіолу $\left(\mathrm{E}_{2}\right)$, тестостерону (TC), вільного трійодтіроніну $\left(\mathrm{T}_{3}\right)$ і вільного тироксину $\left(\mathrm{T}_{4}\right)$ в сироватці крові проводили методом ІФА з використанням комплектів реагентів виробництва НПЛ «Гранум» (Україна): «Кортизол - ІФА», «Прогестерон - ІФА», «Естрадіол - ІФА», «Тестостерон ІФА», «Т3 вільний - ІФА» і «Т4 вільний - ІФА», відповідно.Кількісне визначення компонентів комплементу С3 і C4 в крові і вагінальної рідини проводили імунотурбодіметрічним методом 3 використанням комплектів реагентів «Комплемент С3» і «Комплемент С4» виробництва «PLIVA-Lachema Diagnosticas.r.o» (Чехія). Кількісне визначеннясубпопуляцій Т-лімфоцитів крові і вагінальної рідини проводили методом їх візуалізації в реакції розеткоутворення з моноклональнимі антитілами до Т-лімфоцитів-хелперів (CD4); Т-лімфоцитів кілерів/супресорів (CD8), визначали відношення CD4/CD8 (індекс імунореактивності IPI). Для статистичної обробки отриманих даних використовували пакет комп'ютерних програм Statistica 10 (StatSoft, Inc., USA). 
У минулих роботах були визначені деякі показники імунної системи, які мали значення для розподілу на підгрупи, тобто були пов'язані iз прогресуванням вагінального дисбіозу. До таких показників було

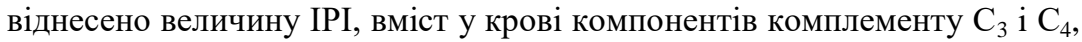
IL1 $\beta$ та IL4. Для цих показників була розрахована залежність від показників системи гормональної регуляції (табл. 1). Величина IPI при нормоценозі прямо залежала від рівню у крові КР, при дисбіозі І ступеню оборотно від рівню ТС, а при дисбіозі ІІ степеню прямо від рівнів $\mathrm{E}_{2}$ та ПГ, а оборотно - від рівню ФСГ. Тобто при розвиненому дисбіозі статеві яєчникові стероїди підтримували нормальні відношення субпопуляцій Т-лімфоцитів.

Таблиця 1

\begin{tabular}{|c|c|c|c|c|c|c|c|c|c|}
\hline \multirow{2}{*}{$\begin{array}{c}\text { Показники } \\
\text { імунітету }\end{array}$} & \multicolumn{3}{|c|}{ Нормоценоз } & \multicolumn{3}{|c|}{ Дисбіоз I ступеню } & \multicolumn{3}{|c|}{ Дисбіоз II ступеню } \\
\hline & ВГК & $\beta$ & $\mathrm{p}$ & ВГК & $\beta$ & $\mathrm{p}$ & BК & $\beta$ & $\mathrm{p}$ \\
\hline \multirow{3}{*}{ IPI } & \multirow{3}{*}{ КР } & \multirow{3}{*}{0,001} & \multirow{3}{*}{0,027} & \multirow{3}{*}{$\mathrm{TC}$} & \multirow{3}{*}{$-0,211$} & \multirow{3}{*}{0,018} & ФСГ & $-0,022$ & 0,018 \\
\hline & & & & & & & $\mathrm{E}_{2}$ & 2,065 & 0,040 \\
\hline & & & & & & & ПГ & 0,017 & 0,001 \\
\hline \multirow{3}{*}{$\mathrm{C}_{3}$} & \multirow{3}{*}{ - } & \multirow{3}{*}{ - } & \multirow{3}{*}{ - } & ЛГ & 0,039 & 0,007 & \multirow{2}{*}{ ПГ } & \multirow{2}{*}{0,026} & \multirow{2}{*}{$1,7 \mathrm{E}-06$} \\
\hline & & & & $E_{2}$ & $-1,677$ & 0,036 & & & \\
\hline & & & & $\mathrm{T}_{3}$ віл. & 0,111 & 0,025 & $\mathrm{TC}$ & $-0,129$ & 0,004 \\
\hline \multirow{5}{*}{$\mathrm{C}_{4}$} & \multirow{5}{*}{$\begin{array}{c}\mathrm{T}_{3} \\
\text { віл. }\end{array}$} & \multirow{5}{*}{$-0,024$} & \multirow{5}{*}{0,026} & \multirow{2}{*}{$\Phi С \Gamma$} & \multirow{2}{*}{0,026} & \multirow{2}{*}{0,020} & ФСГ & 0,006 & 0,038 \\
\hline & & & & & & & $\mathrm{E}_{2}$ & $-0,724$ & 0,016 \\
\hline & & & & $\mathrm{E}_{2}$ & $-1,496$ & $1,2 \mathrm{E}-05$ & ПГ & 0,011 & $5,9 \mathrm{E}-12$ \\
\hline & & & & ПГ & 0,006 & 0,019 & $\mathrm{TC}$ & $-0,031$ & 0,014 \\
\hline & & & & КР & 0,001 & $6,8 \mathrm{E}-05$ & $\mathrm{~T}_{3}$ віл. & 0,022 & 0,002 \\
\hline \multirow{4}{*}{ IL $1 \beta$} & \multirow{4}{*}{ ПРЛ } & \multirow{4}{*}{0,270} & \multirow{4}{*}{0,020} & \multirow{2}{*}{$\mathrm{E}_{2}$} & \multirow{2}{*}{$-27,7$} & \multirow{2}{*}{0,005} & ПГ & 0,567 & 0,002 \\
\hline & & & & & & & $\mathrm{TC}$ & $-3,203$ & 0,036 \\
\hline & & & & \multirow{2}{*}{ КР } & \multirow{2}{*}{0,010} & \multirow{2}{*}{0,037} & $\mathrm{~T}_{3}$ віл. & 2,868 & 0,001 \\
\hline & & & & & & & $\mathrm{T}_{4}$ віл. & $-1,022$ & 0,002 \\
\hline
\end{tabular}


Продовження таблиці 1

\begin{tabular}{|c|c|c|c|c|c|c|c|c|c|}
\hline \multirow{5}{*}{ IL4 } & \multirow{5}{*}{ - } & \multirow{5}{*}{ - } & \multirow{5}{*}{-} & ФСГ & $-0,198$ & 0,021 & \multirow{2}{*}{ ФСГ } & \multirow{2}{*}{$-0,109$} & \multirow{2}{*}{$4,5 \mathrm{E}-04$} \\
\hline & & & & ЛГ & $-0,130$ & 0,005 & & & \\
\hline & & & & $\mathrm{E}_{2}$ & 10,6 & $4,9 \mathrm{E}-05$ & $\mathrm{E}_{2}$ & 7,3 & 0,025 \\
\hline & & & & ПГ & $-0,043$ & 0,016 & ПГ & $-0,114$ & $7,6 \mathrm{E}-11$ \\
\hline & & & & КР & $-0,003$ & 0,017 & $\mathrm{~T}_{3}$ віл. & $-0,241$ & 0,002 \\
\hline
\end{tabular}

Примітки: ВГК - вміст гормону у крові; $T_{4}$ віл. - вільний $T_{4} ; T_{3}$ віл. - вільний $T_{3}$; $\beta$ - коефіцієнти регресії, $p$ - ̈̈х статистична значущість

Рівні у крові компонентів комплементу С3 і С4 при дисбіозі мали низку зв'язків, серед яких пряму залежність виявляли рівні ФСГ, ЛГ, ПГ, КР та вільного $\mathrm{T}_{3}$, а оборотну залежність - рівні $\mathrm{E}_{2}$ та ТС. Отже, $\mathrm{E}_{2}$, який мав прямий зв'язок з мікробним біоценозом, мав оборотну залежність від активації комплементу. 3 цих позицій виключення гормональної стимуляції яєчників при вагінальному дисбіозі може розглядатися як компенсаторна реакція, спрямована на збереження оваріальної функції в умовах патології. Рівень у крові IL1 $\beta$ при дисбіозі також мав оборотну залежність від рівню у крові $\mathrm{E}_{2}$ та ТС, та пряму - від рівню ПГ, що підтверджувало висунуте припущення.Рівень у крові протизапального цитокіну - IL4, на відміну від IL $1 \beta$, мав пряму залежність 3 рівнями $\mathrm{E}_{2}$, та обернену - 3 рівнем ПГ. Обернені залежності виявлені також для рівнів у крові ФСГ, ЛГ, КР та вільного Т. Тобто, згідно до біологічної ролі як антагоністу прозапальнихцитокінів, IL4 при вагінальному дисбіозі мав і протилежні по знаку взаємозв'язки з яєчниковими стероїдами.

Отримані результати по впливу системи гормональної регуляції на показники мікробного біоценозу, місцевої колоніальної резистентності та імунної системи відображали формування єдиної гормональноімунної системи, яка формується в умовах вагінального дисбіозу. Наукова інтерпретація таких даних потребує більш детального аналізу, заснованого на побудові математичних моделей, які здатні показати наявність достеменних зв'язків та, відповідно, - патогенетичних механізмів у багатомірному просторі даних (нейромережева модель).

\section{Література:}

1. Кира, Е.Ф. Бактериальный вагиноз. ООО «Медицинскоеинформационноеагентство. Москва, 2012. 472 с. 
2. Jahic M, Mulavdic M, Nurkic J, Jahic E, Nurkic M. Clinical characteristics of aerobic vaginitis and its association to vaginal candidiasis, trichomonas vaginitis and bacterial vaginosis. Med Arch, 2013. Vol. 67. № 6. P. 428-430.

3. Кан Н.И., Ивандеева О.И., Ванина Л.Н. Взаимосвязь нарушений микрофлоры влагалищного биотопа и особенностей изменения механизмов иммунореактивности у женщин с ожирением. Научный журнал «Вестник» РУДН. Серия медицина, Москва, 2009. № 2. С. 73-77.

4. Шабашова Н.В., Кузьмина Д.А.,Фролова Е.В.,Симбарская М.Л., Учеваткина А.Е.,Филиппова Л.В.,Мирзабалаева А.К.Нарушения местного иммунитета и иммунотерапия Гепоном при хроническом воспалении слизистых оболочек разной локализации. Вестник Медицинской академии последипломного образования. 2010. Т. 2. № 4. С. 59-64.

5. Наумкина Е.В., Рудаков Н.В. Эпидемиологические особенности урогенитальных инфекций, вызванных условно-патогенными возбудителями, при комплексном микробиологическом подходе к диагностике. Омский науч. вестн. 2006. Т. 35. № 1. С. 70-73. 